\title{
SUBSITUSI TEPUNG TERIGU DENGAN TEPUNG MOCAF DALAM PEMBUATAN KUE KERING
}

\author{
Syimil Ihromi ${ }^{*}$, Marianah'1, Yodi Adi Susandi 1
}

1Teknologi Hasil Pertanian, Universitas Muhammadiyah Mataram, syirrilihromi@ummat.ac.id

\begin{tabular}{l}
\hline INFO ARTIKE \\
\hline RiwayatArtikel: \\
Diterima: 15-02-2018 \\
Disetujui: 28-02-2018
\end{tabular}

\section{Kata Kunci:}

Substitusi

Tepung Terigu

Tepung Mocaf

Kue Kering

\section{A. LATAR BELAKANG}

Makanan berbasis tepung terigu telah menjadi makanan pokok banyak negara, salah satunya adalah Indonesia. Salah satu makanan yang digemari adalah kue kering. Kue kering menurut istilah yang sering digunakan untuk kue yang bertekstur keras tapi renyah yang memiliki kadar air yang sangat rendah karena dibuat dengan cara dioven. Kue kering memiliki daya tahan yang cukup lama. Menurut (Hanafi dkk, 1999) Menyatakan bahwa bahan dasar pembuatan kue kering adalah tepung terigu, garam, gula, lemak, telur, susu skim, bahan pengembang (leavening agents).

Tepung terigu adalah tepung atau bubuk halus yang berasal dari biji gandum yang di haluskan, kemudian digunakan untuk pembuatan mie, kue dan roti. Tepung yang berasal dari biji gandum ini terbilang istimewa karena mengandung gluten. Gluten adalah protein yang secara alami terkandung di semua jenis serealia atau bijibijian yang tidak dapat larut dalam air dan bersifat elastis (lentur) sehingga mampu membentuk kerangka yang kokoh dan makanan yang kenyal pada saat dimakan. Bahan dasar Tepung terigu masih diimpor dari luar negeri sehingga perlu alternatif lain menggunakan tepung jenis lain salah satunya tepung mocaf untuk pembuatan kue, mie dan roti.

Mocaf (Modifiet Cassava Flour) yaitu produk olahan singkong yang dimodifikasi dimana keunggulan dari tepung mocaf ini yaitu bahan baku yang tersedia cukup banyak dan harga singkong sebagai bahan baku relatif murah dibandingkan harga gandum sebagai bahan baku terigu. Kelebihan dari tepung mocaf pada efek fisiologis seperti mencegah kanker kolon, mempunyai efek hipoglikemis, namun mocaf juga memiliki kekurangan yaitu kandungan proteinnya sedikit dan tidak memiliki kandungan gluten seperti pada tepung terigu. Pembuatan tepung mocaf menggunakan prinsip modifikasi sel singkong secara fermentasi..Setelah menjadi tepung mocaf bisa digunakan sebagai pengganti tepung terigu atau campuran tepung terigu untuk pembuatan kue kering, mie kering/basah, bihun, pampek, bakso, kerupuk, brownies, dan lainnya.

Tepung mocaf sangat cocok untuk menggantikan tepung terigu untuk kebutuhan industri makanan. Produk makanan apapun yang dihasilkan oleh tepung mocaf akan lebih menguntungkan karena tepung mocaf secara ekonomis ternyata jauh lebih murah dari pada tepung terigu. Hal ini karena bahan baku mudah didapat. Murahnya harga singkong serta proses pengolahan yang tidak membutuhkan teknologi tinggi (Setiavani,2013).

Kue kering yang dibuat dengan subsitusi tepung mocaf diharapkan akan mempunyai kualitas yang lebih baik dari kue-kue umumnya terutama nilai gizi, rasa, kenampakan, dan masa simpan yang panjang sehingga dapat diterima oleh masyarakat.. Tujuan penelitian yaitu 
mengetahui persentase subsitusi tepung terigu dengan tepung mocaf yang tepat dan pengaruhnya terhadap sifat kimia dan organoleptik kue kering

\section{B. METODE PENELITIAN}

\section{Rancangan Penelitian}

Data dalam penelitian ini merupakan data primer yang langsung diperoleh dari hasil penentuan kadar air, kadar abu, kadar pati dan uji organoleptik. Data penelitian dianalisis menggunakan rancangan percobaan yaitu RAL (Rancangan Acak Lengkap)(Hanafiah, 1994). Perlakuan substitusi tepung terigu dengan tepung mocaf dilakukan dalam 6 aras perlakuan dengan 3 kali ulangan. Pendenahan dalam rancangan penelitian ini dapat dilihat pada Tabel 1.

Tabel 1. Pendenahan dalam rancangan percobaan

\begin{tabular}{ccccccc}
\hline & \multicolumn{6}{c}{ Taraf Perlakuan Persentase Substitusi tepung } \\
Ulan & \multicolumn{5}{c}{ Terigu dengan tepung mocaf (\%) } \\
\cline { 2 - 7 } gan & $\mathbf{0}$ & $\mathbf{1 5}$ & $\mathbf{3 0}$ & $\mathbf{4 5}$ & $\mathbf{6 0}$ & $\mathbf{7 5}$ \\
\hline 1 & T0U1 & T1U1 & T2U1 & T3U1 & T4U1 & T5U1 \\
2 & T0U2 & T1U2 & T2U2 & T3U2 & T4U2 & T5U2 \\
3 & T0U3 & T1U3 & T2U3 & T3U3 & T4U3 & T5U3 \\
\hline
\end{tabular}

Keterangan :

$\mathrm{T}=$ Persentase Substitusi tepung Terigu dengan tepung mocaf

$\mathrm{U}=$ ulangan ke 1, 2, 3

Masing-masing perlakuan dilakukan ulangan sebanyak 3 kali ulangan sehingga diperoleh 18 unit percobaan. Apabila hasil analisis ragam berpengaruh nyata, maka dilakukan uji lanjut dengan uji BNJ pada taraf nyata $5 \%$.

\section{Parameter Penelitian}

Parameter yang diamati dalam penelitian ini meliputi uji kimia dan organoleptik. Uji kimia yang dilakukan yaitu penentuan kadar air, kadar pati dan kadar abu menggunakan pengujian berdasarkan Sudarmadji, dkk. 1997. Sedangkan uji organoleptik meliputi warna, aroma, rasa, dan tekstur menggunakan pengujian berdasarkan Kartika, dkk, 1988.

\section{Tempat Penelitian}

Penelitian ini dilaksanakan di laboratorium Pengolahan hasil pertanian dan laboratorium kimia fakultas pertanian universitas muhammadiyah mataram.

\section{Tahapan Penelitian}

Tahapan penelitian diawali dengan penyiapan bahan baku dan bahan pendukung lainnya untuk pembuatan kue kering. Tahapan penelitian dapat dilihat pada gambar 1.

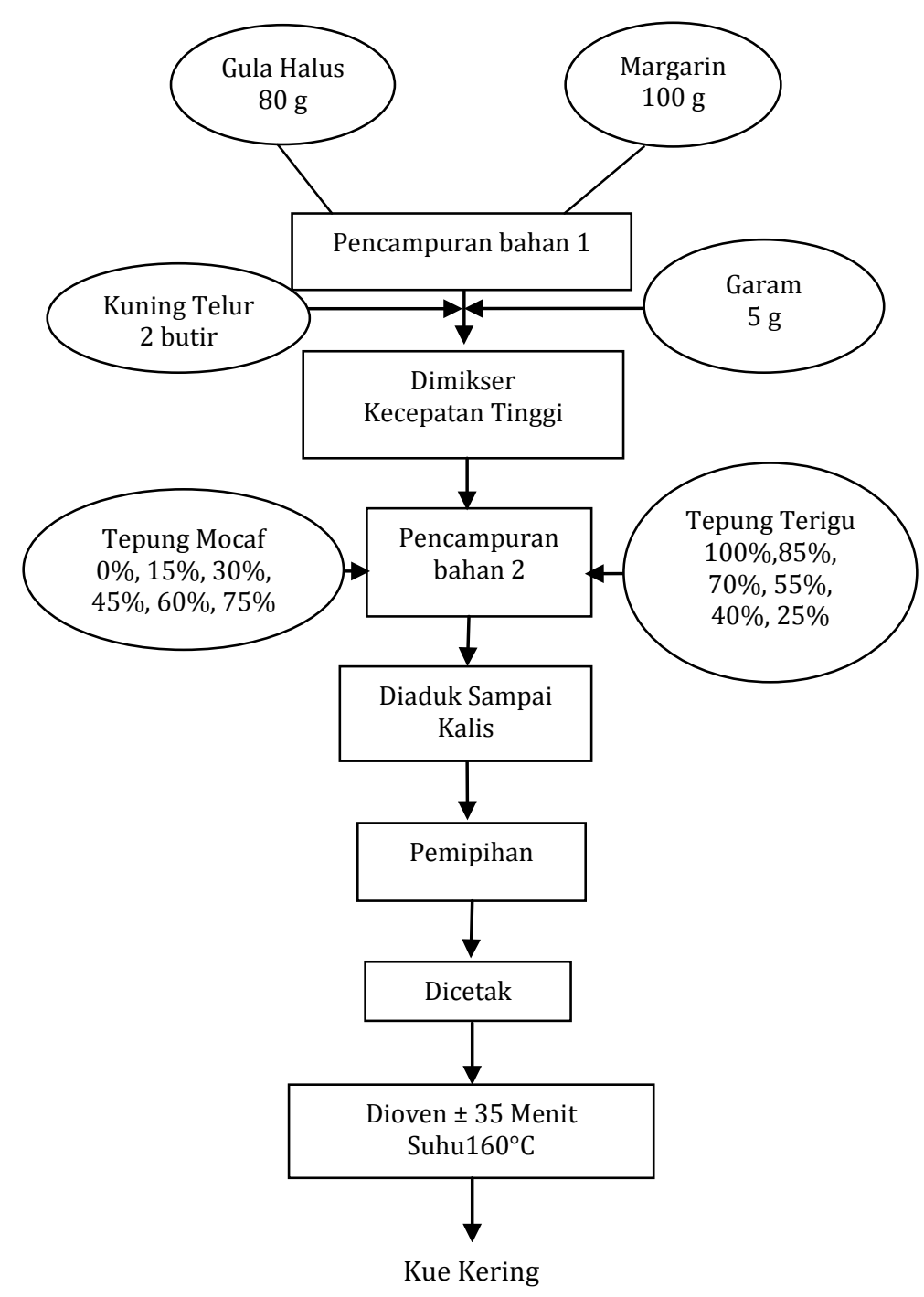

Gambar 1. Diagram Alir Proses Pembuatan Kue Kering (modifikasi Soenardi 2002).

\section{HASIL DAN PEMBAHASAN}

\section{Hasil Penelitian}

Data penelitian dan analisis keragaman hasil dan uji lanjutnya terhadap parameter yang diamati pada kue kering dapat dilihat pada tabel 2 dan tabel 3.

Tabel 2. Purata hasil analisis kadar air, pati dan abu kue kering pada berbagai substitusi tepung terigu dengan tepung mocaf.

\begin{tabular}{cccc}
\hline Perlakuan & Kadar Air & Kadar Pati & Kadar Abu \\
\hline T0 & $11,8215 \mathrm{~b}$ & $13,6133 \mathrm{a}$ & $0,4590 \mathrm{a}$ \\
T1 & $7,5988 \mathrm{a}$ & $13,9400 \mathrm{a}$ & $1,5544 \mathrm{ab}$ \\
T2 & $6,5109 \mathrm{a}$ & $29,9167 \mathrm{~b}$ & $2,9783 \mathrm{~b}$ \\
T3 & $6,1436 \mathrm{a}$ & $33,3000 \mathrm{~b}$ & $3,4720 \mathrm{~b}$ \\
T4 & $6,1039 \mathrm{a}$ & $34,3533 \mathrm{~b}$ & $5,9380 \mathrm{c}$ \\
T5 & $4,6675 \mathrm{a}$ & $35,1033 \mathrm{~b}$ & $6,4915 \mathrm{c}$ \\
\hline BNJ 5\% & 3,1766 & 6,8890 & 2,2269 \\
\hline
\end{tabular}

Keterangan : Angka yang diikuti oleh huruf yang sama pada kolom yang sama tidak berbeda nyata pada taraf $5 \%$. 
Tabel 3. Purata hasil analisis skor nilai aroma, warna, tekstur dan rasa kue kering pada berbagai substitusi tepung terigu dengan tepung mocaf.

\begin{tabular}{ccccc}
\hline Perlakuan & Aroma & Warna & Tekstur & Rasa \\
\hline T0 & 3,50 b & 3,94 & 2,50 & $3,55 \mathrm{~b}$ \\
T1 & 3,44 b & 3,50 & 2,69 & $3,31 \mathrm{ab}$ \\
T2 & $3,31 \mathrm{~b}$ & 3,44 & 2,88 & $3,06 \mathrm{ab}$ \\
T3 & $3,31 \mathrm{~b}$ & 3,31 & 2,94 & $2,88 \mathrm{ab}$ \\
T4 & $3,00 \mathrm{ab}$ & 3,31 & 3,13 & $2,69 \mathrm{ab}$ \\
T5 & $2,38 \mathrm{a}$ & 2,63 & 3,19 & $2,50 \mathrm{a}$ \\
\hline BNJ 5\% & 0,825 & - & - & 0,942 \\
\hline
\end{tabular}

Keterangan: Angka-angka yang diikuti oleh huruf yang sama pada kolom yang sama tidak berbeda nyata pada taraf $5 \%$

\section{Pembahasan}

\section{a. Kadar Air}

Hasil penelitian kadar air menunjukkan bahwa semakin tinggi persentase substitusi tepung terigu dengan tepung mocaf, maka kadar air kue kering semakin rendah. Kadar air tertinggi diperoleh pada perlakuan T0 (porsentase substitusi 100\% dengan tepung mocaf $0 \%$ ) yaitu sebesar 11,8215\%, dan terendah diperoleh pada perlakuan T5 (persentase substitusi tepung terigu 25\% dengan tepung mocaf $75 \%$ ) yaitu sebesar $4,6675 \%$.

Hasil penelitian kadar air kue kering menunjukkan adanya pengaruh perbedaan yang nyata dimana semakin tinggi subsitusi tepung mocaf maka kadar air dari kue kering cenderung semakin menurun. Kadar air yang dihasilkan dari kue kering dipengaruhi oleh perbedaan kadar air bahan baku dimana tepung mocaf memiliki kadar air lebih rendah yaitu sebesar 6,9\% sedangkan kadar air tepung terigu yaitu 12,0\% (Depkes, 1997). Hal ini karena tepung mocaf berfungsi untuk mengikat dan membantu menghasilkan adonan yang homogen karena tepung mocaf lebih fleksibel mudah tercampur dan lebih efesien karena mempunyai daya simpan dan tahan lama sehingga mampu mengikat air dalam suatu bahan. Lebih lanjut Sulaswati (2008) menyatakan bahwa, tepung mocaf setelah dilakukan beberapa proses pemanasan, pengeringan dan ekstrak akan menurunkan kadar air suatu bahan. Pada perlakuan T5 memenuhi kadar air kue kering sesuai standar SNI (1992), yaitu maksimal 5\%

\section{b. Kadar Pati}

Hasil penelitian Kadar Pati menunjukkan bahwa semakin tinggi persentase substitusi tepung mocaf dengan tepung terigu, maka kadar pati kue kering semakin tinggi. Kadar pati kue kering tertinggi diperoleh pada perlakuan T5 (persentase substitusi tepung mocaf 75\% dengan tepung terigu 25\%) yaitu sebesar 35,1033\%. Dan Kadar pati kue kering terendah diperoleh pada perlakuan T0 (persentase substitusi tepung mocaf $0 \%$ dengan tepung terigu $100 \%$ ) yaitu sebesar 13,6133\%. Hasil pengamatan kadar pati kue kering menunjukkan adanya pengaruh nyata dimana semakin tinggi subsitusi tepung mocaf maka semakin tinggi kadar pati dari kue kering yang dihasilkan. Peningkatan kadar pati pada kue kering disebabkan karena tepung mocaf memiliki kadar pati yang tinggi dibandingkan dengan tepung terigu, dimana kadar pati tepung mocaf yaitu $87,33 \%$ dan tepung terigu 60-68\% (Juanda dan cahyono, 2004). Semakin tinggi kandungan pati yang terdapat pada suatu bahan akan mengakibatkan semakin tingginya kadar pati pada kue kering.

\section{c. Kadar Abu}

Hasil penelitian Kadar Abu menunjukkan bahwa semakin tinggi porsentase substitusi tepung mocaf dengan tepung terigu, maka kadar abu kue kering semakin tinggi. Kadar abu kue kering tertinggi diperoleh pada perlakuan T5 (porsentase substitusi tepung mocaf $75 \%$ dengan tepung terigu $25 \%$ ) yaitu sebesar 6,4915, dan Kadar abu kue kering terendah diperoleh pada perlakuan T0 (porsentase substitusi tepung mocaf $0 \%$ dengan tepung terigu $100 \%$ ) yaitu sebesar $0,4590 \%$.

Hasil pengamatan kadar abu kue kering menunjukkan adanya pengaruh nyata dimana semakin tinggi subsitusi tepung mocaf maka semakin tinggi kadar abu dari kue yang dihasilkan. Peningkatan kadar abu kue kering disebabkan karena tepung mocaf memiliki kadar abu yang tinggi yaitu $1,3 \%$, dibandingkan dengan tepung terigu, yaitu 0,4\% (Sri. 2011). Tepung mocaf memiliki kandungan pati yang lebih tinggi dibandingkan tepung terigu, sehingga tepung terigu lebih lembut dibandingkan dengan tepung mocaf.

\section{d. Nilai Aroma}

Hasil penelitian Nilai Aroma menunjukkan bahwa semakin tinggi porsentase substitusi tepung mocaf dengan tepung terigu, maka nilai aroma kue kering semakin rendah. Nilai aroma kue kering tertinggi diperoleh pada perlakuan T0 (porsentase substitusi tepung mocaf $0 \%$ dengan tepung terigu $100 \%$ ) yaitu sebesar 3,50 dengan kriteria suka, dan nilai aroma kue kering terendah diperoleh pada perlakuan T5 (porsentase substitusi tepung mocaf $75 \%$ dengan tepung terigu $25 \%$ ) yaitu sebesar 2,38 dengan kriteria tidak suka.

Hasil pengamatan nilai aroma kue kering menunjukkan adanya pengaruh nyata dimana semakin tinggi subsitusi tepung mocaf maka semakin rendah nilai aroma dari kue yang dihasilkan. Hasil penelitian terhadap aroma kue kering menghasilkan tingkat kesukaan dari 2,38 dengan kriteria tidak suka 
sampai 3,500 dengan kriteria suka. Hal ini dikarenakan kue kering yang dihasilkan lebih beraroma khas dari tepung mocaf meskipun telah melakukan proses pengolahan. Semakin banyak tepung mocaf yang ditambahkan maka aroma kue kering yang dihasilkan semakin beraroma tepung mocaf. Hasil penelitian terhadap sifat organoleptik aroma dalam penelitian ini menunjukkan tingkat kesukaan panelis cenderung menurun seiring dengan semakin tingginya substitusi tepung mocaf.

\section{e. Nilai Warna}

Hasil penelitian Nilai Warna menunjukkan bahwa semakin tinggi porsentase substitusi tepung mocaf dengan tepung terigu, maka nilai warna kue kering cendrung semakin rendah namun setelah dilakukan analisis statistik tidak menunjukkan perbedaan yang nyata. Nilai warna kue kering tertinggi diperoleh pada perlakuan T0 (porsentase substitusi tepung mocaf $0 \%$ dengan tepung terigu $100 \%$ ) yaitu sebesar 3,94 dengan kriteria coklat muda, dan nilai warna kue kering terendah diperoleh pada perlakuan T5 (porsentase substitusi tepung mocaf $75 \%$ dengan tepung terigu $25 \%$ ) yaitu sebesar 2,63 dengan kriteria agak coklat.

Pada hasil penelitian menunjukkan bahwa skor warna kue kering hasil penelitian panelis berkisar antara 2,63 dengan criteria agak coklat sampai 3,94 dengan criteria coklat muda. Warna yang dimiliki kue kering dipengaruhi oleh komposisi penambahan tepung mocaf yang memiliki warna agak coklat yang becampur dengan tepung terigu yang berwarna putih sehingga menampilkan berubah warna coklat muda dengan semakin tingginya penambahan tepung mocaf maka warna semakin disukai oleh panelis. Hal ini disebabkan karena kombinasi antara tepung mocaf dengan tepung terigu.

Menurut Wijaya (2002) warna warna yang baik untuk kue kering adalah kuning kecoklatan dan tergantung bahan yang digunakan. Warna tepung yang warna putih akan menghasilkan kue kering yang kuning kecoklatan, sedang warna tepung yang agak kecoklatan akan menghasilkan kue kering warna lebih coklat.

\section{f. Nilai Tekstur}

Hasil penelitian Nilai Tekstur menunjukkan bahwa semakin tinggi porsentase substitusi tepung mocaf dengan tepung terigu, maka nilai tekstur kue kering cendrung semakin tinggi namun setelah dilakukan analisis statistik tidak menunjukkan perbedaan yang nyata. Nilai tekstur kue kering terendah diperoleh pada perlakuan T0 (porsentase substitusi tepung mocaf $0 \%$ dengan tepung terigu $100 \%$ ) yaitu sebesar 2,50 dengan kriteria agak renyah, dan nilai tekstur kue kering tertinggi diperoleh pada perlakuan T5 (porsentase substitusi tepung mocaf $75 \%$ dengan tepung terigu $25 \%$ ) yaitu sebesar 3,19 dengan criteria renyah.

Hasil penelitian skor nilai tekstur tertinggi diperoleh pada perlakuan T5 (porsentase substitusi tepung mocaf $75 \%$ dengan tepung terigu $0 \%$ ) yaitu sebesar 3,19 dengan kriteria agak renyah dan terendah pada perlakuan T0 (porsentase substitusi tepung mocaf $0 \%$ dengan tepung terigu 100\%) sebesar 2,50 dengan kreteria mendekati agak renyah. Hal ini disebabkan oleh semakin tinggi level penambahan tepung mocaf mengakibatkan tekstur semakin renyah dan disukai oleh panelis.

\section{g. Nilai Rasa}

Hasil penelitian Nilai Rasa menunjukkan bahwa semakin tinggi persentase substitusi tepung mocaf dengan tepung terigu, maka skornilai rasa kue kering semakin menurun. Skor nilai rasa kue kering terendah diperoleh pada perlakuan T5 (persentase substitusi tepung mocaf $75 \%$ dengan tepung terigu 25\%) yaitu sebesar 2,50 dengan kriteria agak enak, dan nilai rasa.

Skor nilai rasa memiliki pengaruh yang nyata terhadap sifat organoleptik rasa pada kue kering tepung mocaf. Hal ini dikarenakan tepung terigu yang tidak mempunyai aroma sedangkan tepung mocaf beraroma khas sehingga rasa kue kering hanya identik dengan rasa mocaf dan kurang disukai oleh panelis karna rasanya kurang enak. Menurut Wijaya (2002) rasa kue kering cenderung lebih dekat dengan aroma. Rasa kue kering yang baik adalah gurih dan manis sesuai bahan yang digunakan dalam adonan.

\section{SIMPULAN DAN SARAN}

\section{SIMPULAN}

1. Semakin tinggi persentase subsitusi tepung terigu dengan tepung mocaf maka kadar air semakin menurun, sedangkan kadar pati dan kadar abu cenderung semakin tinggi.

2. Semakin tinggi subsitusi tepung terigu dengan tepung mocaf dalam pembuatan kue kering maka skor nilaiseperti aroma, rasa,dan warna semakin menurun, sedangkan pada skor nilai tekstur semakin meningkat.

3. Subsitusi tepung terigu menggunakan tepung mocaf sampai batas T5 (75\%) menghasilkan kue kering baik sifat kimia maupun organoleptik masih baik

\section{SARAN}

1. Dalam pembuatan kue kering dengan subsitusi tepung terigu dengan tepung mocaf tidak boleh lebih dari 75\%. 
2. Perlu penelitian serupa terhadap lama simpan kue kering.

\section{UCAPAN TERIMA KASIH}

Penulis mengucapkan terima kasih kepada Universitas Muhammadiyah Mataram atas dukungan materil dalam melaksanakan penelitian ini sehingga berjalan dengan lancar dan mendapatkan hasil yang baik.

\section{DAFTAR RUJ UKAN}

[1] Astawan, M. Dan S. Widowati. 2006. Evaluasi Mutu Gizi dan Indeks Glikemik Ubi jalar sebagai Dasar Pengembangan Pangan Fungsional. Laporan Penelitian RUSNAS, Bogor

[2] Departemen Kesehatan RI, 1997. Daftar Komposisi Bahan Makanan. Bhratara Karya Aksara, Jakarta.

[3] Desrosier, 2008. Teknologi Pengawetan Pangan Penerjemah M. Muljahorjo. UI- pres, Jakarta.

[4] Hanafiah K. A., 1994. Rancangan Percobaan, Teori dan Aplikasi. Raja Grafindo Persada, Jakarta.

[5] Juanda, Dede J.S. dan Bambang Cahyono.2004. Ubi Jalar Budidaya dan Analisis. Dalam cahyono, Muhammad Mursyid. 2004. Study Pembuatan Permen Ubi Jalar Susu Sebagai Alternatif Divesifikasi Pengolahan. Skripsi S1 jurusan TPHP, FP UGM.Yokyakarta

[6] Kartika, B., Hastuti,P dan Supartono, w. 1988. Pedoman Uji Indrawi Bahan Pangan. PAU

[7] Setiavani, G. 2013. Teknologi Pembuatan Makanan Dengan Menggunakan Tepung Mocaf Sebagai Subsitusi Tepung Terigu. http://www.stppmedan.ac.id.. Diakses tanggal 20 maret 2015.

[8] SNI, 1992 . SNI Kue Kering-Kering (SNI 012937-1992). Badan Standar Nasional. Jakarta, Diakses Pada Tanggal 15 November 2012. Charley, 1982. Dasar-Dasar Penelitian Bidang Teknik. Jakarta.

[9] Sri, 2011. Jurnal Pemanfaatan Singkong Menjadi Tepung Mocaf Untuk Pemberdayaan Masyarakat Sumber Univet Bantara: Suharjo.

[10] Sudarmadji, S., Haryono B. dan Suhardi (1997). Prosedur Analisa untuk Bahan Makanan dan Pertanian. Liberty, Yogyakarta.

[11] Sulaswati. 2008. Pengukuran Status Gizi Dengan Antropometri Gizi. http://www.eurekaindonesia.org/ antropometrigizi.pdf. diakses 10 November 2010.

[12] Winarno, 1997. Kimia Pangan dan Gizi Gramedia Pustaka Utama. Jakarta. 